\title{
Pro-inflammatory Profiles of Indonesian Adult Men with Central Obesity: a Preliminary Study on TNF- $\alpha$, sTNFR-2 and IL-1 $\beta$
}

\author{
C.R. Sartika ${ }^{1,2}$, Andi Wijaya ${ }^{1,2}$, and Suryani As'ad ${ }^{1}$ \\ 'Postgraduate Program in Biomedical Science-Clinical Chemistry, Faculty of Medicine, Hassanuddin University, Makassar \\ ${ }^{2}$ Prodia Clinical Laboratory \\ ${ }^{3}$ SEAMEO-TROPMED Regional Center for Community Nutrition, Faculty of Medicine, University of Indonesia, Jakarta.
}

\section{Abstract}

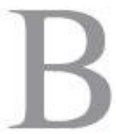

ACKGROUND: Central obesity is closely associated with chronic inflammation, characterized by abnormal cytokine production such as $\mathbb{I}-1 \beta$, tumor necrosis factor- $\alpha(\mathrm{TNF}-\alpha)$ and tumor necrosis factor receptor-2 (TNFR-2). Central obesity and chronic inflammation form a complex link with insulin resistance, leading to the development of type-2 diabetes mellitus (T2DM) and cardio-vascular disease (CVD). Knowing the coinciding occurrence of chronic inflammation and central obesity, this study aimed to examine pro-inflammatory cytokine profiles of Indonesian adult men with central obesity.

METHODS: This cross-sectional study recruited 80 apparently healthy Indonesian adult men, aged 23-53 years with waist circumference of $64-125 \mathrm{~cm}$. This study was done in Jakarta. Measurements included clinical parameters like systolic blood pressure (SBP), diastolic blood pressure (DBP), fasting blood glucose (FBG), aspartate amino transferase (AST), alanine amino transferase (ALT), creatinine, high sensitivity C-reactive protein (hsCRP); anthropometric parameters, namely weight, height and waist circumference; and pro-inflammatory cytokines TNF- $\alpha$, soluble TNFR-2 (sTNFR-2) and $\amalg-1 \beta$.

RESULTS: Basic characteristics of the subjects showed linear increase in values of SBP, DBP and the serum concentrations of AST, ALT, FBG, GFR, hsCRP ( $p<0,005$ respectively) with the degree of obesity. sTNFR-2 and IL-1 $\beta$ positively correlated with hsCRP ( $\mathrm{rs}=0.277, \mathrm{p}=0.013$ and $\mathrm{rs}=0.257, \mathrm{p}=0.022$, respectively), $\mathrm{WC}$ ( $\mathrm{rs}=0.380$, $\mathrm{p}=0.001$ and $\mathrm{rs}=0.400, \mathrm{p}<0.001$, respectively) and body mass index (BMI) (rs=0.364, p=0.001 and $r s=0.399$, $\mathrm{p}<0.001$, respectively). Moreover, TNF- $\alpha$ did not show correlations with hsCRP, WC, and BMI.

CONCLUISON: There was a linear increase in the serum concentrations of sTNFR-2 and IL-1 $\beta$ in subjects with central obesity. Both pro-inflammatory markers, correlated with hsCRP, WC and BMI, but TNF- $\alpha$ did not. sTNFR-2 and $I L-1 \beta$ were, therefore, considered as valid biomarkers to indicate chronic inflammation in Indonesian adult men with central obesity.

KEYWORDS: Central obesity, TNF- $\alpha$, soluble TNFR-2 (sTNFR-2) and IL-1 $\beta$.

\section{Introduction}

The worldwide epidemic of obesity, fostered by the modern lifestyle characterized by the lack of physical activity and energy-dense diet, has increased incrementally in many developed and developing countries. Indonesia is not an exempted country. The prevalence of overweight and obesity among Indonesian adults, using the body mass 
index (BMI) cut-off $>25 \mathrm{~kg} / \mathrm{m} 2$, was $48.97 \%$ in men and $40.65 \%$ in women (1). The concomitant occurrence of central/abdominal obesity has become a great concern, given it is the major risk leading to cardio-vascular disease (CVD), type 2 diabetes (T2DM), and other degenerative diseases like cancer $(2,3)$.

It should be pointed out that different fat depots have distinct metabolic characteristics, leading to individual differences in the impact of obesity on cardiometabolic risks. Obesity is known to be associated with low-grade chronic inflammation, marked by increased production of pro-inflammatory cytokines like tumor necrosis factor- $\alpha$ (TNF- $\alpha$ ), interleukin-1 $\beta$ (IL-1 $\beta$ ) and $\mathrm{C}$-reactive protein (CRP) (4) due to increasing number of infiltrating macrophages population in adipose tissue. Pro-inflammatory cytokines produced in adipose tissue interfere with signals and activation of insulin on adipose tissue, liver and muscle, leading to insulin resistance (5), evidenced by consistent links between inflammation with insulin resistance, T2DM and CVD (2,4, 6-8).

The roles of TNF- $\alpha$ associated with insulin resistance have been well documented in both animal and human studies (9). TNF- $\alpha$ can induce disruption of tyrosine phosphorylation in insulin receptor and insulin receptor substrate-1 (IRS-1), and activate serine/threonine phosphorylation in IRS-1 (10). Experimentally, inhibition of TNF- $\alpha$ in rodent models improved insulin sensitivity significantly (11). Concentrations of TNF- $\alpha$ were reported to be associated positively with BMI and central obesity. In a reciprocal pattern, TNF- $\alpha$ concentrations decline in a linear manner with weight loss, and the decline of TNF- $\alpha$ improved insulin sensitivity $(10,12,13)$.

As a consequence of increasing production of TNF- $\alpha$, adipose tissue of obese individuals expressed soluble tumor necrosis factor receptor-2 (sTNFR-2). Hotamisligil et al. (11) showed that the expression of TNFR- 2 mRNA in fat tissue was two-fold and the STNFR- 2 concentrations in the blood circulation was six-fold in obese women compared to non-obese woman. The bound TNF- $\alpha$ and TNFR-2 complex directly binds to the TNF receptor associated factor (TRAF), and then go downstream on the path to activate intra-cellular nuclear factor kappa $\mathrm{B}(\mathrm{NF} x \mathrm{~B})$ and c-Jun N-terminal kinase/stress activated protein kinase (JNK/SAPK). 11

IL-1 $\beta$, produced by monocytes and macrophages, exerts its biological function by binding to IL-1 type I receptor, which then activates the inhibitor- $x \mathrm{~B}$ kinase/ nuclear factor- $x \mathrm{~B}$ (IKK/NF- $x \mathrm{~B})$ pathway and the three types of mitogen-activated protein kinase mitogen-activated protein kinase (MAPKs): extracellular-regulated kinase (ERK), JNK, and p38MAPK. Previous research showed that the expression of $\mathrm{IL}-1 \beta$ and its receptor increased in obese adipose tissue, and increased the risk of T2DM. 8

TNF- $\alpha$, sTNFR- 2 and IL- $1 \beta$ could play an important role in insulin resistance and CVD related obesity. But until now there has been no comprehensive information on TNF- $\alpha$, sTNFR- 2 and $I L-1 \beta$ in Indonesia. Therefore this study aimed to examine the proinflammatory cytokines profile and their interaction in Indonesian adult men with central obesity.

\section{Methods}

Subjects were recruited from patients having checkups at the Prodia Clinical Laboratory in Jakarta, employees of some companies and members of nearby communities who were willing to participate in this study. These preliminary results were part of a bigger project on Inflammation and Angiogenesis in Indonesian Adult Men with Central Obesity undertaken by the Principal Investigator (SCR) in Jakarta. Eighty apparently healthy Indonesian male adults, aged 25-55 were eligible for the study. No subjects had renal, hepatic, endocrine, and oncological diseases, fever, received anti-diabetic drugs, or other drugs known to affect lipoprotein metabolism for at least 3 weeks prior to the study.

Subjects were divided into 3 groups: non-obese group with waist circumference (WC) $<90 \mathrm{~cm}(\mathrm{n}=25)$, obese I group with WC $90-100 \mathrm{~cm}(\mathrm{n}=27)$, and obese II group with $\mathrm{WC}>100 \mathrm{~cm}(\mathrm{n}=28)$. This subject classification was based on the Asia Pacific criteria for central obesity cutoffs recommended by the International Diabetes Federation (IDF) 14 and World Health Organization (WHO).(15)

All subjects agreed to sign informed consent prior to the commencement of the study. The proposal and clinical protocols of this study were approved by the Medical Ethics Committee of the Faculty of Medicine, Hasanuddin University.

Blood pressure was measured using a standardized method as described in the previous study (16).

The anthropometric indicators were measured twice. The mean values were used in the analyses. Body weight (BW), height and waist circumference were measured using a standardized method as described in the previous study (16). 
Fasting blood specimens were collected in the morning between 07:00-10:00 am. Plasma and serum were separated immediately by centrifugation and aliquots were frozen at $-20^{\circ} \mathrm{C}$ for batched analysis for TNF- $\alpha$, sTNFR-2 and IL-1 $\beta$. Routine biochemical parameters like serum high sensitivity C-reactive protein (hSCRP), fasting blood glucose (FBG), aspartate amino transferase (ALT), alanine aminotransferase (ALT), creatinine, total bilirubin concentrations were determined immediately soon after the blood separation process. All biochemical analyses were performed at Prodia Clinical Laboratory.

Serum glucose, creatinine, ALT, AST, total bilirubin and hsCRP concentrations were measured using the Prodia Clinical Laboratory's routine chemistry procedures. Serum AST, ALT, plasma glucose concentrations were determined using an automated glucose oxidase method. Serum creatinine concentrations were determined using the International Federation of Clinical Chemistry (IFCC) method and reagents manufactured by Roche diagnostic (B) Mannheim, Germany). Subjects were defined suffering from chronic kidney disease if the value of glomerular filtration rate (GFR) was $<60 \mathrm{ml} /$ minute $/ 1,73 \mathrm{~m} 2$ in line with the National Kidney Foundation-Kidney Disease Outcomes Quality Initiative (NKF-KDOQI) guidelines 2000 (17). GFR was calculated using the Cockroft and Gault formula.

[(140-age) $\mathrm{X}$ body weight/ $\mathrm{kg}$ ]

$\operatorname{GFR}(\mathrm{mL} / \mathrm{min})=\overline{[72 \mathrm{X} \text { creatinine serum }(\mathrm{mg} / \mathrm{dL})]}$

Plasma $h s \mathrm{CRP}$ was determined using chemiluminescent immunometric asssay. Commercially available kits and reagents were purchased to measure serum hsCRP (for use on Immulite ${ }^{\circledR} 2000$ systems produced by Siemens).

With respect to pro-inflammatory cytokines, commercially available kits were purchased to measure serum TNF- $\alpha$ (Quantikine ${ }^{\circledR}$ hS High Sensitivity ELISAs Human TNF- $\alpha /$ TNFSF1A produced by R\&D Systems, Inc., Minneapolis, MN, USA), TNFR-2 (Quantikine ${ }^{\circledR}$ Human sTNF RII/TNFRSF1B produced by R\&D Systems, Inc., Minneapolis, MN, USA), and IL-1 $\beta$ (Quantikine ${ }^{\circledR}$ HS
High Sensitivity ELISAs Human IL-1 $1 / \mathrm{IL}-1 \mathrm{~F} 2$ produced by R\&D Systems, Inc., Minneapolis, MN, USA).

Data analysis was done using SPSS 13.0 statistical analysis software for Windows (SPSS Inc., Chicago, IL, USA). Distributions of continuous variables were assessed for normality using the Kolmogorov-Smirnov. For continuous variables with normal distributions, such as anthropometric and biochemical measures, descriptive statistics were presented as mean \pm SD. Statistical analysis was performed using a one-way analysis of variance for a quantitative dependent variable by a single factor (independent) variable. Associations between continuous variables with approximately normal distributions were described using Spearman's correlation coefficients. All tests were two-sided and considered significant at $\mathrm{p}<$ 0.05 .

\section{Results}

Table 1 describes the clinical and biochemical characteristics of the subjects, by central obesity categories, with mean, median, minimum and maximum values. Subjects' age ranged from 26 to 56 years old, with WC ranged from 65 to $125 \mathrm{~cm}$. Other clinical and biochemical indicators were in the range of the study inclusion criteria.

Table 2 shows the mean value of clinical and biochemical variables of non-obese, obese I and II subjects, indicating significant differences between the groups. There was linear increase in the values of SBP and DBP, and almost all biomarker concentrations with the degree of central obesity, except for serum total bilirubin concentrations. Serum TNF- $\alpha$ concentrations did not show significant differences between the groups. Mean values of sTNFR-2 and IL-1 $\beta$ showed significant differences between the groups of obese I and II (both at $\mathrm{p}<0.05$ ).

Table 3 shows that sTNFR- 2 and $\mathrm{IL}-1 \beta$ positively correlated with hsCRP ( $\mathrm{rs}=0.277, \mathrm{p}=0.013$ and $\mathrm{rs}=0.257$, $\mathrm{p}=0.022$, respectively), $\mathrm{WC}(\mathrm{rs}=0.380, \mathrm{p}=0.001$ and $\mathrm{rs}=$ $0.400, \mathrm{p}<0.001$, respectively) and BMI ( $\mathrm{rs}=0.364, \mathrm{p}=$ 0.001 and $\mathrm{rs}=0.399, \mathrm{p}<0.001$, respectively). However, TNF- $\alpha$ did not show any correlation with hsCRP, WC, and BMI. 
Table 1. Clinical and biochemical characteristics of the subjects

\begin{tabular}{|c|c|c|c|c|c|c|c|}
\hline Variable & Units & Mean & \pm & s.d. & Median & Min & Max \\
\hline Age & year & 37.1 & \pm & 5.7 & 38.0 & 26.0 & 51.0 \\
\hline \multicolumn{8}{|c|}{ Clinical and anthropometric indicators } \\
\hline WC & $\mathrm{cm}$ & 94.0 & \pm & 11.8 & 94.0 & 65.0 & 125.0 \\
\hline BMI & $\mathrm{kg} / \mathrm{m} 2$ & 27.7 & \pm & 4.5 & 27.4 & 18.1 & 45.1 \\
\hline SBP & $\mathrm{mmHg}$ & 111.7 & \pm & 9.0 & 110.0 & 90.0 & 130.0 \\
\hline DBP & $\mathrm{mmHg}$ & 76.2 & \pm & 6.8 & 80.0 & 60.0 & 89.0 \\
\hline \multicolumn{8}{|c|}{ Biochemical indicators } \\
\hline AST & $U / L$ & 23.5 & \pm & 7.5 & 22.0 & 13.0 & 52.0 \\
\hline ALT & $U / L$ & 31.2 & \pm & 18.3 & 26.0 & 6.0 & 97.0 \\
\hline Total Bilirubin & $\mathrm{mg} / \mathrm{dL}$ & 0.8 & \pm & 0.3 & 0.7 & 0.4 & 2.3 \\
\hline FBG & $\mathrm{mg} / \mathrm{dL}$ & 85.8 & \pm & 7.4 & 86.0 & 69.0 & 104.0 \\
\hline GFR & $\mathrm{ml} / \mathrm{mnt}$ & 121.7 & \pm & 26.8 & 117.9 & 74.2 & 191.8 \\
\hline hsCRP & $\mu \mathrm{g} / \mathrm{dL}$ & 2.1 & \pm & 2.0 & 1.4 & 0.2 & 9.3 \\
\hline \multicolumn{8}{|c|}{ Inflammatory markers } \\
\hline TNF- $a$ & $\mathrm{pg} / \mathrm{mL}$ & 3.31 & \pm & 3.13 & 2.53 & 1.23 & 26.92 \\
\hline sTNFR-2 & $\mu \mathrm{g} / \mathrm{mL}$ & 2.18 & \pm & 0.44 & 2.09 & 1.41 & 3.49 \\
\hline IL-1 $\beta$ & $\mathrm{pg} / \mathrm{mL}$ & 0.38 & \pm & 0.68 & 0.14 & 0.01 & 3.55 \\
\hline
\end{tabular}

Data are expressed as means \pm s.d. Abbreviations: WC, waist circumference; BMI, body mass index; SBP, systolic blood pressure; DBP, diastolic blood pressure; AST, aspartate amino transferase; ALT, alanine amino transferase; GFR, glomerular filtration rate; hsCRP, high sensitivity C-reactive protein; TNF- $\alpha$, tumor necrotic factor- $\alpha$; sTNFR-2, soluble tumor necrotic factor receptor-2; IL-1 $\beta$, interleukin-1 $\beta$; s.d., standard deviation. 
Tabel 2. Differences in clinical and biochemical indicators of the subjects, by central obesity categories.

\begin{tabular}{|c|c|c|c|c|c|c|c|c|c|c|}
\hline \multirow{3}{*}{$\begin{array}{l}\text { Variables } \\
\text { Age }\end{array}$} & \multirow{3}{*}{$\begin{array}{l}\text { Units } \\
\text { Year }\end{array}$} & \multicolumn{9}{|c|}{$\begin{array}{l}\text { Degree of central obesity } \\
\text { Mean } \pm \text { s.d }\end{array}$} \\
\hline & & \multicolumn{3}{|c|}{$\begin{array}{l}\text { Non Obese } \\
\quad(n=25)\end{array}$} & \multicolumn{3}{|c|}{$\begin{array}{l}\text { Obese I } \\
(n=27)\end{array}$} & \multicolumn{3}{|c|}{$\begin{array}{l}\text { Obese II } \\
(n=28)\end{array}$} \\
\hline & & 35.4 & \pm & 7.6 & 37.2 & \pm & 5.2 & 38.4 & \pm & 4.9 \\
\hline \multicolumn{11}{|c|}{ Clinical indicators } \\
\hline SBP & $\mathrm{mmHg}$ & 107.9 & \pm & $8.0^{\mathrm{b}}$ & 113.1 & \pm & 9.4 & 113.8 & \pm & $8.6^{b}$ \\
\hline DBP & $\mathrm{mmHg}$ & 72.8 & \pm & $7.1^{\mathrm{ab}}$ & 77.7 & \pm & $6.1^{\mathrm{a}}$ & 77.7 & \pm & $6.2^{b}$ \\
\hline \multicolumn{11}{|c|}{ Biochemicals indicators } \\
\hline AST & $U / L$ & 20.8 & \pm & $3.8^{b}$ & 21.8 & \pm & $5.8^{\mathrm{c}}$ & 27.5 & \pm & $9.6 b^{c}$ \\
\hline ALT & $U / L$ & 21.7 & \pm & $9.6^{\mathrm{ab}}$ & 28.6 & \pm & $12.1^{\mathrm{ac}}$ & 42.2 & \pm & $23.3 b^{c}$ \\
\hline Tot Bil & $\mathrm{mg} / \mathrm{dL}$ & 0.8 & \pm & 0.2 & 0.8 & \pm & 0.4 & 0.8 & \pm & 0.2 \\
\hline FBG & $\mathrm{mg} / \mathrm{dL}$ & 84.2 & \pm & $6.0^{\mathrm{b}}$ & 84.6 & \pm & $6.5^{c}$ & 88.4 & \pm & $8.8^{\mathrm{bc}}$ \\
\hline GFR & $\mathrm{mL} / \mathrm{mnt}$ & 105.7 & \pm & $21.8^{\mathrm{b}}$ & 115.8 & \pm & $19.8^{c}$ & 142.4 & \pm & $23.7^{\mathrm{bc}}$ \\
\hline hsCRP & $\mu \mathrm{g} / \mathrm{dL}$ & 1.02 & \pm & $1.06^{\mathrm{ab}}$ & 2.17 & \pm & $2.11^{\mathrm{a}}$ & 3.14 & \pm & $2.04^{b}$ \\
\hline \multicolumn{11}{|c|}{ Inflammatory Markers } \\
\hline TNF- $a$ & $\mathrm{pg} / \mathrm{mL}$ & 3.78 & \pm & 5.08 & 2.15 & \pm & 1.56 & 3.23 & \pm & 1.75 \\
\hline STNFR-2 & $\mu \mathrm{g} / \mathrm{mL}$ & 2.02 & \pm & $0.36^{b}$ & 2.10 & \pm & $0.29^{c}$ & 2.40 & \pm & $0.53^{\mathrm{bc}}$ \\
\hline IL-1 $1 \beta$ & $\mathrm{pg} / \mathrm{mL}$ & 0.16 & \pm & $0.23^{b}$ & 0.19 & \pm & $0.23^{c}$ & 0.76 & \pm & $1.01^{\mathrm{bc}}$ \\
\hline
\end{tabular}

Data are expressed as means \pm s.d. Abbreviations: WC, waist circumference; BMI, body mass index; SBP, systolic blood pressure; DBP, diastolic blood pressure; AST, aspartate amino transferase; ALT, alanine amino transferase; Tot bil, total bilirubin; GFR, glomerular filtration rate; hsCRP, high sensitivity C-reactive protein; TNF- $\alpha$, tumor necrotic factor- $\alpha$; sTNFR-2, soluble tumor necrotic factor receptor-2; IL-1 $\beta$, interleukin-1 $\beta$; s.d., standard deviation. Differences among groups were determined by one-way analysis of variance; a.significantly different between non-obese and obese I subjects $(p<0.05)$; b. significantly different between non-obese and obese II subjects $(p<0.05)$; $c$. significantly different between obese I and obese II subjects $(p<0.05)$.

Tabel 3. Relationships between inflammatory cytokines with hsCRP, waist circumference and body mass index.

\begin{tabular}{|c|c|c|c|c|c|c|c|}
\hline \multirow[t]{2}{*}{ Variable } & \multirow[t]{2}{*}{ Units } & \multicolumn{2}{|l|}{ TNF- $\alpha$} & \multicolumn{2}{|c|}{ sTNFR-2 } & \multicolumn{2}{|l|}{ IL-1 $\beta$} \\
\hline & & $r_{s}$ & p & $r_{s}$ & $p$ & $r_{s}$ & p \\
\hline hsCRP & $\mu \mathrm{g} / \mathrm{dL}$ & 0.056 & NS & 0.277 & 0.013 & 0.257 & 0.022 \\
\hline WC & $\mathrm{Cm}$ & 0.173 & NS & 0.380 & 0.001 & 0.400 & 0.000 \\
\hline BMI & $\mathrm{kg} / \mathrm{m} 2$ & 0.183 & NS & 0.364 & 0.001 & 0.399 & 0.000 \\
\hline
\end{tabular}

Description: WC, waist circumference; $h s C R P$, high sensitivity C-reactive protein; TNF- $\alpha$, tumor necrotic factor- $\alpha$; sTNFR-2, soluble tumor necrotic factor receptor-2; IL-1 $\beta$, interleukin- $1 \beta ; r_{s}$, Spearman correlation (2-tailed); $p$, value of significant; $N S$, non significant 


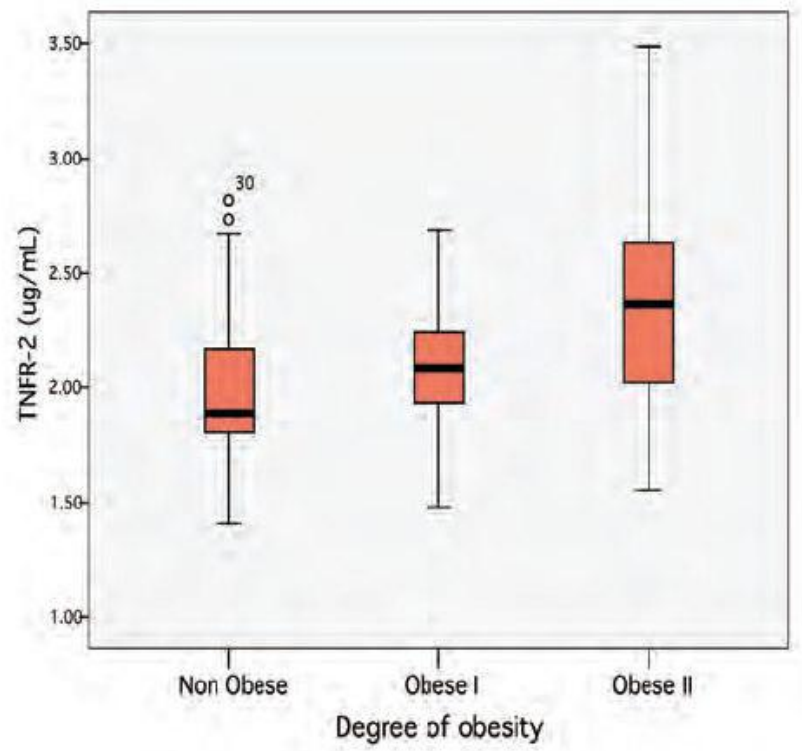

Figure 1. Differences in sTNFR-2 of the subjects, by central obesity categories.

\section{Discussion}

Prospective study has shown that central obesity is a major risk factor for type 2 diabetes and cardiovascular disease, and $\mathrm{WC}$ is the best predictors of intra peritoneal and posterior subcutaneous abdominal adipose tissue mass. 18 The increase in ALT, GFR and hsCRP concentrations and SBP and DBP value were accompanied by increasing WC. An increasing value of physical examination and laboratory test in obesity due to metabolism disorders (19).

Table 2 shows the concentration of pro-inflammatory cytokine, sTNFR- 2 and $\mathbb{I}-1 \beta$ decreased from non-obese group to the obese group $I$, and then it increased significantly to obese II. The possibility is due to body's compensatory mechanisms against obesity, in which the concentration of pro-inflammatory factors in the early occurrence of obesity has not been expressed in the circulation. When the state of obesity continues, the expression of proinflammatory cytokines is released into the circulation. Mechanism of biological variation in the body is unknown, since there are currently no published data about the body compensatory mechanism of pro-inflammatory cytokines to obesity.

Several studies have been published pointing out that the state of obesity associated with low levels of inflammation (4). Both sTNFR- 2 and IL- $1 \beta$ concentration showed increased in the circulation consistent with the development of adipose tissue and increased of

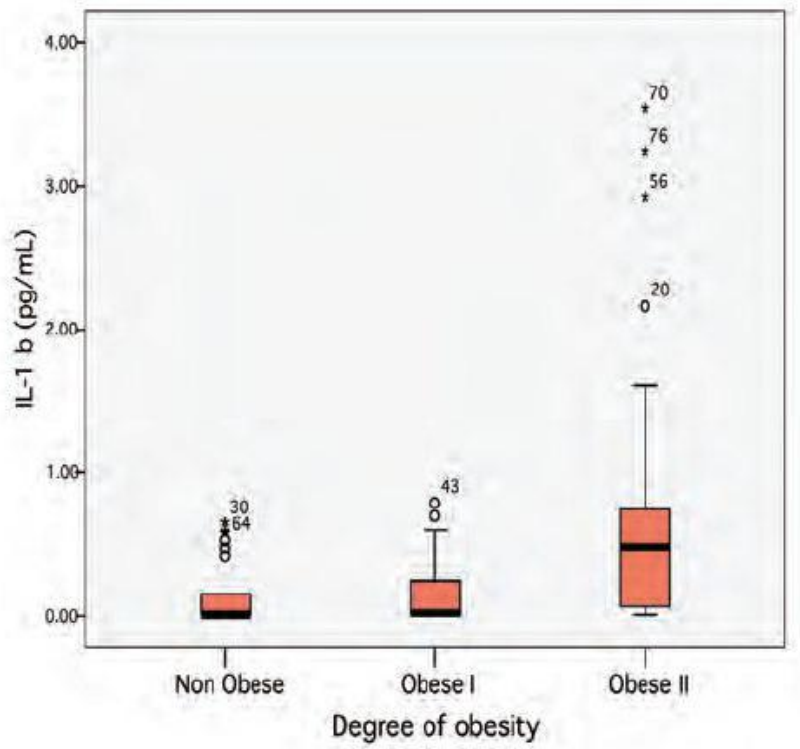

Figure 2. Differences in IL-1 $\beta$ of the subjects, by central obesity categories.

hsCRP which is a biochemical marker for systemic low grade inflammation (20). Infiltration of monocytes and macrophages were found in the growing adipose tissue (8). sTNFR- 2 concentration correlated positively with TNF- $\alpha$ in the circulation, since the release of STNFR-2 stimulated by TNF- $\alpha$ (21). sTNFR-2 plays as modulators of biological function of TNF- $\alpha$ (22). TNF- $\alpha$ in obesity did not show any difference between groups, it may be that TNF- $\alpha$ in the circulation was quickly bound and neutralized by TNF- $\alpha$ receptor that became very low in concentration. mTNR-2 expression was higher in obese than non-obese. Hence the concentrations of sTNFR-2 were found to increase in the serum obese individuals (23).

Examination of TNF- $\alpha$ activity is more reliable by using concentrations of sTNFR- 2 as compared with TNF- $\alpha$ concentration of the total, because the sTNFR-2 protein is more easily detected in the plasma and the concentration remains elevated at a longer period (24).

Concentration of $I L-1 \beta$ was higher in obese II groups. IL-1 $\beta$ decreases insulin induced glucose transport in adipocytes mainly by inhibiting IRS- 1 expression through a reduction in IRS-1 mRNA that is dependent on ERK pathway activation and by a posttranscriptional mechanism that is independent of ERK. IL-1 $\beta$ that is produced by resident macrophages in adipose tissue could act in synergy with TNF- $\beta$ and IL- 6 to impair adipocytes biology that could be an important event in the development of the insulin resistance (8). 


\section{Conclusion}

There was a linear increase in the serum concentrations of sTNFR- 2 and IL-1 $\beta$ in subjects with central obesity. Both pro-inflammatory markers were correlated with hsCRP, WC and BMI, but this did not occur on TNF- $\alpha$. Therefore, sTNFR- 2 and $I L-1 \beta$ are considered as valid biomarkers to indicate chronic inflammation in Indonesian adult men with central obesity.

\section{Acknowledgements:}

This study was fully funded by the Prodia Foundation for Research and Training. We are indebted to the technical staff of the Prodia Clinical Laboratory, Clinical Trial and Research and Development Departements for their valuable assistance in undertaking specimen collection in the field and in biochemical assessments.

\section{References:}

1. Witjaksono, F. Body mass index and waist circumference among Indonesian adult from urban communities. Indonesian Society for the Study of Obesity (ISSO). 3rd National Obesity Symposium (NOS III) 2004;83-84.

2. Grundy, S. M. Metabolic syndrome: connecting and reconciling cardiovascular and diabetes worlds. J Am Coll Cardiol 2006; 47:1093-1100.

3. Trayhurn, P. White adipose tissue grafts-keeping in contact. Am J Physiol Reg Int Comp Physiol 2005; 289:297-298.

4. Sartika, C.R., Lukito, W. dan Wijaya, A. Hubungan antara inflamasi, stres oksidatif dan disfungsi endotel pada sindrom metabolik pria dewasa, kajian terhadap pemeriksaan biokimia: adiponektin total anti oksidan status dan hsCRP. Tesis Pascasarjana Program S2 UNHAS. Makassar 2006.

5. Trayhurn, P. and Wood, I.S. Horizons in Nutritional Science. Adipokines: Inflammation and the pleiotropic role of white adipose tissue. British J Nutr 2004;92:347-355.

6. Wellen, K.E. and Hotamisligil, G.S. Obesity-induced inflammatory changes in adipose tissue. J Clin Invest 2003;112:1785-1788

7. Yudkin, J.S. Adipose tissue, insulin action and vascular disease: Inflammatory signals. Int J Obes Relat Disord 2003; 27:S25-S28.

8. Jager, J., Gre 'meaux, T., Cormont, M., Marchand-Brustel, Y.L. and Tanti, J-F. Interleukin-1 $\square$-induced insulin resistance in adipocytes through down-regulation of insulin receptor substrate-1 expression. Endocrinology 2007;148:241251.
9. Hotamisligil GS. The role of TNFalpha and TNF receptors in obesity and insulin resistance. J Intern Med 1999; 245:621-5

10. Good, M., Newell, F.M., Haupt, L.M., Whitehead, J.P., Hutley, L.J., Prins, J.B. TNF and TNF receptor expression and insulin sensitivity in human omental and subcutaneous adipose tissue - influence of BMl and adipose distribution. Diabetes Vasc Dis Res 2006;3:26-33

11. Hotamisligil GS. Mechanisms of TNF-alpha-induced insulin resistance. Exp Clin Endocrinol 1999;107:119-125.

12. Qi, C. and Pekala, P.H. Tumor necrosis factor alpha induced insulin resistance in adipocytes. Soc Exp Biol Med 2000;223;128-135.

13. Hube $\mathrm{F}$ and Hauner $\mathrm{H}$. The role of TNF-alpha in human adipose tissue: prevention of weight gain at the expense of nsulin resistance? Horm Metab Res 1999;31:626-631.

14. Alberti, K.G., Zimmet, P. and Shaw, J. IDF epidemiology task force consensus group: The metabolic syndrome: a new worldwide definition. Lancet 2005;366:1059-1062.

15. World Health Organization. Obesity: preventing and managing the global epidemic. WHO/NUT/98.1. Geneva, Switzerland1998.

16. Sartika CR, LukitoW, Wijaya A. Adiponectin, Total Antioxidant Status, and high sensitivity C-Reactive Protein in Indonesian Men with Metabolic Syndrome. Med J Indones 2009 (in press)

17. National Kidney Foundation-Kidney Disease Outcomes Quality Initiative (NKF-KDOQI) quidlines 2000. www.Kidney.org. (Accessed in August 2007)

18. Chan, D. C., Watts, G.F., Barrett, P.H.R. and Burke, V. Waist circumference, waist-to-hip ratio and body mass index as a predictors of adipose tissue compartments in men. Q J Med 2003; 96:441-447

19. Ohkawa, S., Odamaki, M., Ikegaya, N., Hibi, I., Miyaji, K. and Kumagai, H. Association of age with muscle mass, fat mass and fat distribution in non-diabetic haemodialysis patients. Nephrol Dial Transplant 2005;20:945-951.

20. Packard, R.R.S. and Libby, P. Inflammation in atherosclerosis: from vascular biology to biomarker discovery and risk prediction. Clin Chem 2008; $54: 24-38$.

21. Dinarello, C.A. Biology of interleukin 1. Fed Am Soc Exp Biol 1998;2:108-115.

22. Stiehl, D.P., Jelkmann, W., Wenger, R.H. and HellwigBürgel, T. Normoxic induction of the hypoxia-inducible factor $1 \mathrm{~K}$ by insulin and interleukin- $1 \mathrm{~L} \square$ involves the phosphatidylinositol 3-kinase pathway. Fed Eur Biochem Soc Lett 2002;512:157-162.

23. Diez-Ruiz, A., Tilz, G.P., Zangerle, R., Baier-Bitterlich, G., Wachter, H. and Fuchs, D. Soluble receptors for tumour necrosis factor in clinical laboratory diagnosis. Eur $\mathrm{J}$ Haematol 1995; 54:1-8

24. Zahorska-Markiewicz, B., Janowska, J., OlszaneckaGlinianowicz, M. and Zurakowski, A. Serum concentrations of TNF- $\alpha$ and soluble TNF- $\alpha$ receptors in obesity. Int J Obes Relat Disord 2000;24:1392-1395 